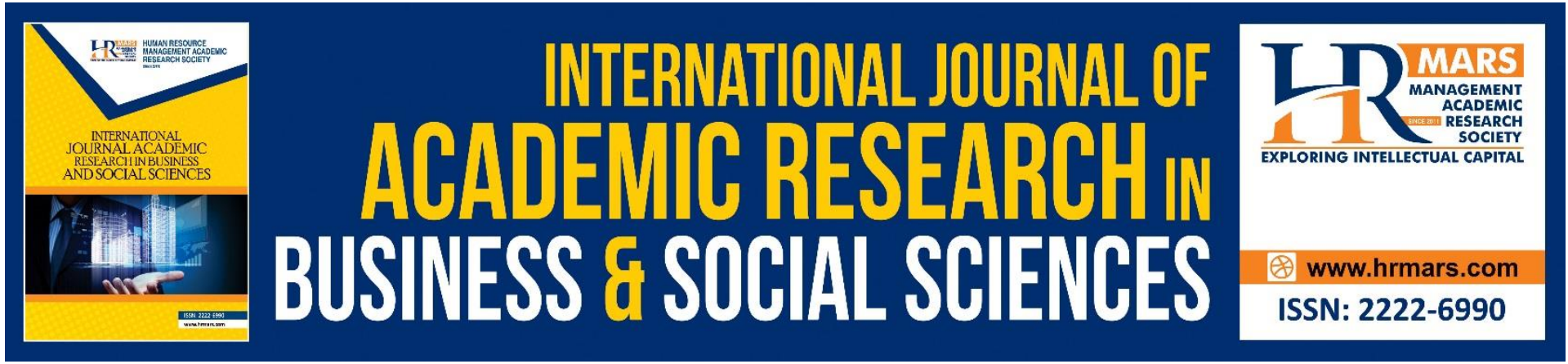

\title{
Wooden Sculpture Inspired Islamic Calligraphy Character as to Show Dynamism, Interlocking, Cultural Symbol in Public Space
}

Burhanuddin Bakri, Ramlan Abdullah

To Link this Article: http://dx.doi.org/10.6007/IJARBSS/v11-i9/11034

DOI:10.6007/IJARBSS/v11-i9/11034

Received: 06 July 2021, Revised: 28 July 2021, Accepted: 19 August 2021

Published Online: 14 September 2021

In-Text Citation: (Bakri \& Abdullah, 2021)

To Cite this Article: Bakri, B., \& Abdullah, R. (2021). Wooden Sculpture Inspired Islamic Calligraphy Character as to Show Dynamism, Interlocking, Cultural Symbol in Public Space. International Journal of Academic Research in Business and Social Sciences, 11(9), 511--514.

Copyright: (c) 2021 The Author(s)

Published by Human Resource Management Academic Research Society (www.hrmars.com)

This article is published under the Creative Commons Attribution (CC BY 4.0) license. Anyone may reproduce, distribute, translate and create derivative works of this article (for both commercial and non-commercial purposes), subject to full attribution to the original publication and authors. The full terms of this license may be seen at: http://creativecommons.org/licences/by/4.0/legalcode

Vol. 11, No. 9, 2021, Pg. 511 - 514

Full Terms \& Conditions of access and use can be found at http://hrmars.com/index.php/pages/detail/publication-ethics 


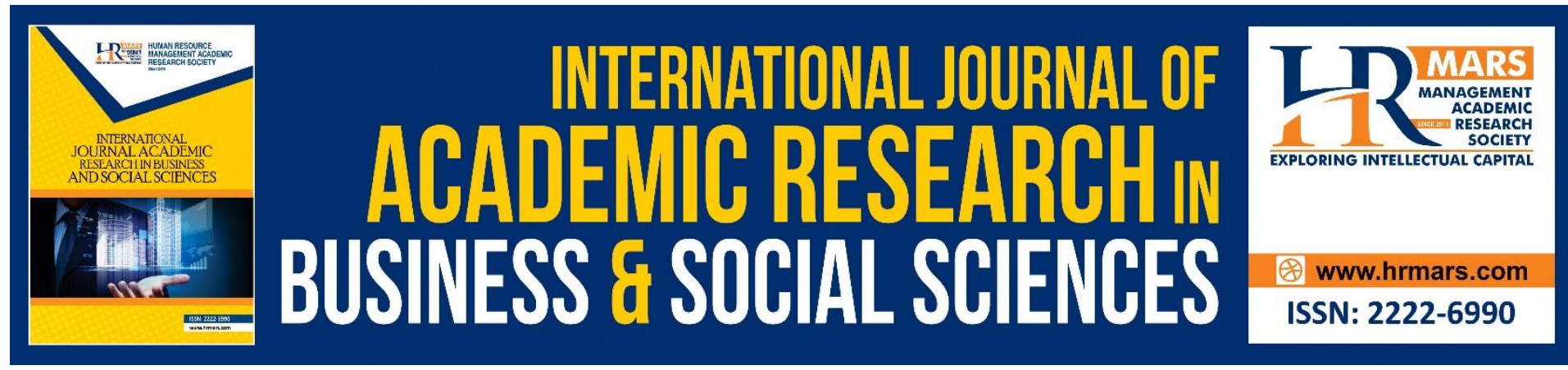

\title{
Wooden Sculpture Inspired Islamic Calligraphy Character as to Show Dynamism, Interlocking, Cultural Symbol in Public Space
}

\author{
Burhanuddin Bakri, Ramlan Abdullah \\ Department of Fine Art, Faculty of Art \& Design Universiti Teknologi MARA \\ Shah Alam 40450 Selangor \\ Email: ramla278@uitm.edu.my
}

\begin{abstract}
This study aims to investigate in greater depth the application of Islamic calligraphy and to create sculptures. It is hoped that the sculptures created will help explain Islamic calligraphy, which has been transformed into dynamic elements that interact with physical space and is twisted, interlocked, intertwined, and represent cultural symbols. The sculpture created is also intended to distinguish crafts and fine art on a grander scale. In addition, the concept of intertextuality will assist this project in providing a clear context for the artwork. Indeed, the addition to formalistic studies leads to the development of form and appearance. The emphasis should be placed on the content and meaning of the work produced.
\end{abstract}

Keywords: Islamic Calligraphy, Sculptures, Dynamic, Physical, Cultural Symbol, Crafts, Fine Art, Intertextuality

\section{Introduction}

My idea is about the Islamic calligraphy and Jawi script. I want to explore the aesthetics of Islamic calligraphy (AI Faruqi, 1985). Islamic calligraphy is a sacred script, and I always look at the potential and concern to examine the extension of Islamic calligraphy. First, I refer to artefacts as my inspiration, such as inscription stone, Kiswah Kaabah, woodcarving, signage, mosque, etcetera. Then, I will look at the local and Middle Eastern artists who use Islamic calligraphy to inspire and study composition, style, and design. Next, I refer to master and continue with my style. This research intends to propose and propagate Islamic calligraphy in sculpture. Islamic calligraphy writing is only a two-dimensional shape, but it can also be developed into a three-dimensional form. The combination of the different disciplines will elevate the value and make it more intriguing and exciting. Setting a two-dimensional shape into a three-dimensional structure will add more aesthetic value because it will involve other elements. Besides, it can also attract the public to appreciate Islamic calligraphy, Jawi writing (Shamsuddin, 1986; Rahman, 2010), and sculpture simultaneously. So, combining Islamic calligraphy and sculpture will give more interesting elements such as dynamic, flow, movement, physical space, interlocking and many more. These new elements can take Islamic calligraphy to another level and create more potential and possible ideas to explore in the future. 


\section{Method}

The primary data I obtained was through my observations. Through this observation, the related information is analysed. Fundamental data is critical because it involves my own experience in analysing. Apart from my own experience with Islamic calligraphy, I also met with some experts in the field related to Islamic calligraphy to add and strengthen the information in my study. In addition, I also get visual study data from the environment and places that use Islamic calligraphy, such as mosques, shops and art exhibitions that I attend. Traditional objects or artefacts are also visual data for me to analyse, such as stone inscriptions, wood calligraphy (Noor \& Khoo, 2012), daggers, and others to understand the philosophy behind the traditional artefacts. The review from related data is essential for me to find relevant information such as history, background and literacy studies (Ariffin, 2017; Diah, 2013; Noor \& Khoo, 2012). In addition, the information I get from reading material is necessary to know more deeply about my research and written evidence or academic reference sources that I can use to enhance my study and research.

As an artist, I have several sources of inspiration in work, whether in the form of another artist's work used as a reference or traditional artefacts in giving me ideas to create. I find this source of inspiration very helpful for me to further and develop my ideas. For example, I often refer to close and located objects in my environment, such as the mosque's dome, calligraphy writing in the surau, verses of the Quran, road signboards, and so on. These objects can inspire me by examining the form of writing, writing style, composition, and so on, which I then do according to my class. What is seen from my environment is very helpful in inspiring me to create or develop my ideas. Even if it is just a daily object or an object often seen, design, composition, style, and shape help study and research. In my opinion, this reference material or artefact represents its context, such as elements of history, tradition, culture, beliefs, knowledge, identity and others.

\section{Results and Discussion}

My artwork is a monumental sculpture. I use Islamic calligraphy (Yahya, 1986; Musa \& Aziz, 2009) as my subject. As a Malay Muslim, I am interested in exploring Islamic calligraphy to show my belief and faith. As we know, Islamic calligraphy or "khat" is the highest form of Islamic art (Zain, 2003; Zain, 2006). I get inspired by Islamic calligraphy because the writing itself is very aesthetic, artistic, unique, and so elegant-the paper also shows discipline and precision. But, unfortunately, the traditional Islamic calligraphy is only in2dimensional forms (visual space). But in my artwork, I try to extend the idea of Islamic calligraphy into threedimensional structures (physical space) and continuity in the area (Yahya, 1986; Battuta, 2005). This idea is about a combination of cross-discipline between traditional and modern approaches. Besides, I intend to popularise and propagate Islamic calligraphy or "khat" in making contemporary artwork.

Combining these two disciplines is fascinating because Islamic calligraphy will involve other and new elements when it is transformed into sculpture. Usually, the traditional Islamic calligraphy is only two dimensional and flat on the surface. However, when the Islamic calligraphy is translated into sculpture, the possible elements will get involved, such as flow, movement, dynamic, interlocking, space, physical form and twisted form of Islamic calligraphy. Therefore, we need to explore the other dimension or potential element of Islamic calligraphy to make it relevant and prevalent in our society. Modern Malaysian art is art produced by Malaysian artists assuming Western modernist methods and philosophy in 
artmaking, but under the conditions and influences of the Malaysian life -thus giving the artwork a Malaysian "flavour" or "identity".

Material wise, I choose wood because, for me, this material has its uniqueness, characteristics and aesthetic. This material also portrays the tradition because this material is general and original from nature. In making this artwork, I need to follow the step by step sketching, shaping, forming and constructing this sculpture. As far as the process is concerned, I need to use several techniques and skills to make the fabrication process fluently.

\section{Conclusion}

To sum up, in Malaysia, there are very few sculptors who produced artworks that are based on Jawi calligraphy. However, several artists the Jawi calligraphy as a subject matter or idea creating a sculpture. Further study on Jawi calligraphy has equipped me with various information and new findings related to the art of Arabic calligraphy and representing the beauty of Islam. The greatness of God's creation itself, Islamic art, aligns with the concept of beauty and can enlighten people about God's power. In sculpture making, the Jawi calligraphy has potential as a subject matter. The Jawi calligraphy can also be developed into various forms and shapes to make it more enjoyable. It can also help to embrace the Jawi calligraphy in making an artwork. The Jawi calligraphy is full of potentials and should be an inspiration or idea in sculpture making. Jawi calligraphy as a public art also symbolises our country as an Islamic nation. Besides, it also helps to elevate our national culture and identity.

\section{Acknowledgements}

The authors acknowledge this artistic research publication was support under the UiTM grant (600RMC/DANA5/3/BESTARI(TD)(001/2020).

\section{References}

Al Faruqi, L. I. (1985). Islam and art. National Hijra Council.

Ariffin, T. S. (2017). Getaran. Kuala Lumpur: Balai Seni Lukis Negara

Battuta, I. (2005). I 4. The Rihla. The Adventures of Ibn Battuta: A Muslim Traveler of the Fourteenth Century, 310.

Diah, A. (2013). Awal Hurouf Asal humour by Husin Hourmain. Subang Jaya, Selangor: Core Design gallery Sdn Bhd

Shamsuddin, I. (1986). Tulisan Jawi Satu Catatan Bibliografi, Kuala Lumpur: Dewan Bahasa dan Pustaka.

Yahya, M. M. (1986). Ensiklopedia Sejarah Islam, jilid 1. Bangi, Selangor Darul Ehsan: Penerbit UKM [Universiti Kebangsaan Malaysia].

Musa, H., \& Aziz, A. Y. A. (2009). Pemerkasaan Kembali Tulisan Jawi. Jurnal Akademi Seni Budaya \& Warisan Kebangsaan (ASWARA).

Noor, F., \& Khoo, E. (2012). Spirit of wood: The art of Malay woodcarving. Tuttle Publishing.

Rahman, A. (2010). Khat dan Jawi: Mutiara Kesenian Islam Sejagat. Malaysia.

Zain. D. H. M. Z. (2006). Manifestasi Tulisan "Jawi". Malaysia, Jabatan Muzium Malaysia.

Zain. D. H. M. Z. (2003). Formalisma Tampak Dalam Seni Khat \& Seni Tampak Malaysia: Balai Seni Lukis Negara. 